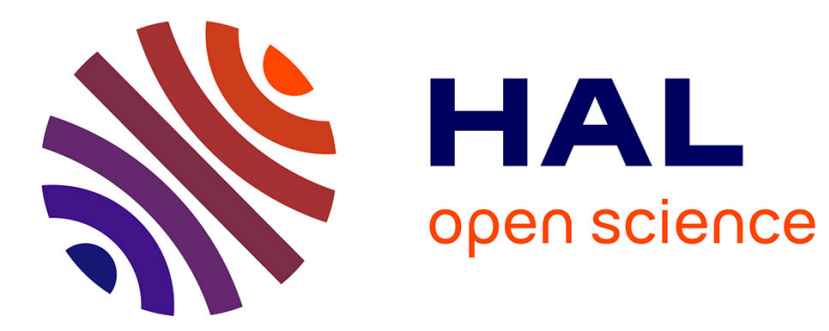

\title{
Synthesis of Ni-poor NiO nanoparticles for p-DSSC applications
}

Baptiste Polteau, Franck Tessier, François Cheviré, Laurent Cario, Fabrice Odobel, Stéphane Jobic

\section{- To cite this version:}

Baptiste Polteau, Franck Tessier, François Cheviré, Laurent Cario, Fabrice Odobel, et al.. Synthesis of Ni-poor NiO nanoparticles for p-DSSC applications. Solid State Sciences, 2016, 54, pp.37-42. 10.1016/j.solidstatesciences.2015.10.007 . hal-01217791

\section{HAL Id: hal-01217791 \\ https://hal.science/hal-01217791}

Submitted on 29 Oct 2015

HAL is a multi-disciplinary open access archive for the deposit and dissemination of scientific research documents, whether they are published or not. The documents may come from teaching and research institutions in France or abroad, or from public or private research centers.
L'archive ouverte pluridisciplinaire $\mathbf{H A L}$, est destinée au dépôt et à la diffusion de documents scientifiques de niveau recherche, publiés ou non, émanant des établissements d'enseignement et de recherche français ou étrangers, des laboratoires publics ou privés. 


\section{Synthesis of Ni-poor NiO nanoparticles for p-DSSC applications}

Baptiste Polteau $^{\mathrm{a}}$, Franck Tessier ${ }^{\mathrm{a}}$, François Cheviré ${ }^{\mathrm{a}}$, Laurent Cario ${ }^{\mathrm{b}}$, Fabrice Odobel ${ }^{\mathrm{c}}$, Stéphane Jobic $^{b}$

${ }^{a}$ Institut des Sciences Chimiques de Rennes (UMR CNRS 6226), Université de Rennes 1, 263 avenue du Général Leclerc, 35042 Rennes cedex, France

${ }^{\mathrm{b}}$ Institut des Matériaux Jean Rouxel, Université de Nantes, CNRS, 2 rue de la Houssinière, 44322 Nantes cedex 3, France

${ }^{\mathrm{c}}$ CEISAM, Université de Nantes, CNRS, 2 rue de la Houssinière, 44322 Nantes cedex 3, France

\section{ABSTRACT}

To improve the performances of $p$-Dye Sensitized Solar Cell (p-DSSC) for the future, the synthesis of modified p-type nickel oxide semiconductor, commonly used as photocathode in such devices, was initiated with $\mathrm{Ni}_{3} \mathrm{O}_{2}(\mathrm{OH})_{4}$ as precursor. This specific nickel oxyhydroxide was first characterized by X-ray photo-electron spectroscopy and magnetic susceptibility measurements. Then its thermal decomposition was thoroughly studied in order to control the particles size of the as-prepared $\mathrm{NiO}$ nanopowders. Low temperature decomposition in air of this precursor allows the formation of $\mathrm{Ni}_{1-\mathrm{x}} \mathrm{O}$ nanoparticles with a large amount of $\mathrm{Ni}$ vacancies and specific surface areas up to $250 \mathrm{~m}^{2} \cdot \mathrm{g}^{-1}$. Its ammonolysis at $250^{\circ} \mathrm{C}$ leads to nanostructured $\mathrm{N}$-doped $\mathrm{NiO}(\mathrm{NiO}: \mathrm{N})$ materials.

Keywords : Synthesis, Ni-poor NiO, Nitrogen doping, Nanoparticles 


\section{Introduction}

Over the past decade, p-type semiconductors (p-SC) have known a renewed interest for applications for light-emitting diodes, transistors, solar cells, etc. In particular, since the achievement of the first Dye Sensitized Solar Cells (DSSC) by Grätzel in 1991 [1], a new generation of solar cells has been developed where the n-type SC is replaced by a p-type one [2]. Such devices are based on the photoinjection of holes instead of electrons in the external circuit. To date nickel oxide $(\mathrm{NiO})$ is the reference p-type semiconductor for p-DSSC applications [3]. However yields are still far from those of n-DSSC and many studies aim to replace $\mathrm{NiO}$ by nanoparticles of $\mathrm{CuAlO}_{2}, \mathrm{CuGaO}_{2}, \mathrm{CuCrO}_{2}$ or $\mathrm{NiCo}_{2} \mathrm{O}_{4}$ to achieve higher photovoltaic performances [4-7]. Following our recent synthesis of Ndoped $\mathrm{ZnO}$ nanoparticles with large amount of $\mathrm{Zn}$ vacancies (up to 20\%) and stabilization of p-type charge carriers [8], we focus on the preparation of $\mathrm{Ni}$-poor $\mathrm{NiO}$ and $\mathrm{N}$-doped $\mathrm{NiO}$ nanoparticles to improve the p-type semiconductivity of $\mathrm{NiO}$. Its origin is still not totally elucidated but is commonly attributed to a nickel non-stoichiometry inducing a $\mathrm{Ni}^{3+} / \mathrm{Ni}^{2+}$ mixed valence in $\mathrm{Ni}_{1-\mathrm{x}} \mathrm{O}$. The nanostructuration will also be a key factor to optimize the p-SC/Dye contact surface. Indeed, to integrate perfectly a p-SC in a p-DSSC, a high specific surface area is necessary to coat the largest amount of dye molecules on $\mathrm{NiO}$ nanoparticles to favor the exchange of charge carriers and high photogenerated current. The nanostructuration could also promote a change in the chemical formulas with variation of the $\mathrm{Ni}^{3+} / \mathrm{Ni}^{2+}$ ratio that governs the conducting behavior. Moreover, the substitution of one nitrogen atom for one oxygen atom should allow the increase of the concentration and the mobility of positive charge carriers $\left(\mathrm{O}^{2-} \rightarrow \mathrm{N}^{3-}+\mathrm{h}^{+}\right)$in order to optimize the injection of holes in the electrical circuit of the p-type cell, and thus its performances. We discuss in this work the thermal decomposition of a nickel oxyhydroxide precursor under air and ammonia that leads to nanostructured $\mathrm{Ni}$-poor $\mathrm{NiO}$ and $\mathrm{N}$-doped $\mathrm{NiO}$ respectively with very high specific surface areas. 


\section{Experimental}

\subsection{Measurements}

X-Ray diffraction. X-Ray diffraction patterns were recorded in the $5-120^{\circ} 2 \theta$ range on a Panalytical X'PERT Powder $(\mathrm{Cu} \mathrm{K \alpha}, 40 \mathrm{kV}, 40 \mathrm{~mA})$ diffractometer. In situ temperature $\left(30-700{ }^{\circ} \mathrm{C}\right.$ range) X-Ray diffraction patterns were recorded in the $10-90^{\circ} 2 \theta$ range on a Bruker D8 Advance diffractometer using $\mathrm{Cu}$ K-L2,3 radiation. All phase analyses were performed using the HighScore Plus software and all data refinements were carried out with the Fullprof suite software [9].

Chemical analysis. Nitrogen and oxygen contents were determined with a Leco TC-600 analyzer using the inert gas fusion method. Nitrogen was detected as $\mathrm{N}_{2}$ by thermal conductivity and oxygen as $\mathrm{CO}_{2}$ by infrared detection.

Density measurements. The Micromeritics AccuPyc 1330 system was used for density measurements by pycnometry under He pressure.

Specific Surface Area measurements. The Brunauer-Emmet-Teller (BET) specific surface area measurements were carried out with a Micromeritics FlowSorb II 2300 instrument using a mixture of $\mathrm{N}_{2} / \mathrm{He}(30 \% / 70 \%)$ as gas analyzer.

X-ray Photoelectron Spectroscopy. XPS spectra $(\mathrm{Mg} \mathrm{K}-\mathrm{L} 3=1253.6 \mathrm{eV})$ were collected in a Leybold-Heraeus ultrahigh vacuum environment with an analyzer operating in the constant pass energy mode $(31.5 \mathrm{eV})$. All spectra were calibrated in energy using $\mathrm{C} 1 \mathrm{~s}=284.7 \mathrm{eV}$ as a reference. Transmission electron microscopy. Transmission electron microscopy (TEM) analyses were realized on a Hitachi H9000NAR (300 kV, Scherzer resolution $0.18 \mathrm{~nm}$ ) microscope.

Magnetic measurements. Magnetic measurements were performed on a Quantum Design SQUID magnetometer (MPMS XLS 5). The data were collected in the temperatures range from 2 to $300 \mathrm{~K}$ under a magnetic field of 5000 Oe. 


\subsection{Synthesis of nickel oxyhydroxide nanoparticles}

The nickel oxyhydroxide precursor $\left(\mathrm{Ni}_{3} \mathrm{O}_{2}(\mathrm{OH})_{4}\right)$ was prepared as previously reported [10]. A strong alkaline solution was prepared by dissolving $5.1 \mathrm{~g}$ of sodium hydroxide $(\mathrm{NaOH}, 98 \%$ Sigma-Aldrich) in $36 \mathrm{~mL}$ of a sodium hypochlorite solution ( $\mathrm{NaClO}, 5 \%$ available chlorine Acros) used as an oxidizing agent [11]. $15.5 \mathrm{~g}$ of nickel sulfate $\left(\mathrm{NiSO}_{4}, 6 \mathrm{H}_{2} \mathrm{O}, 99 \%\right.$ Acros) were dissolved in $35 \mathrm{~mL}$ of distilled water. Then the alkaline solution was slowly added dropwise to the nickel sulfate aqueous solution under vigorous stirring to promote the precipitation according to the following chemical reaction (1):

$$
3 \mathrm{NiSO}_{4}+6 \mathrm{NaOH}+\mathrm{NaClO} \rightarrow \mathrm{Ni}_{3} \mathrm{O}_{2}(\mathrm{OH})_{4}+3 \mathrm{Na}_{2} \mathrm{SO}_{4}+\mathrm{NaCl}+\mathrm{H}_{2} \mathrm{O}
$$

The resulting black suspension was kept under stirring for $90 \mathrm{~min}$ at room temperature. The precipitate was separated from the solution by centrifugation at $2500 \mathrm{rpm}$ for $5 \mathrm{~min}$, dispersed in distilled water and separated again by centrifugation. These dispersion/separation cycles were repeated 6 times in order to remove any impurities and the resulting precipitate was dried in an oven at $70{ }^{\circ} \mathrm{C}$ overnight. Finally, the product was crushed in an agate mortar to obtain the nickel oxyhydroxide powder precursor which was immediately stored in a desiccator to avoid any surface hydration.

\subsection{Synthesis of nickel-poor nickel oxide}

$600 \mathrm{mg}$ of $\mathrm{Ni}_{3} \mathrm{O}_{2}(\mathrm{OH})_{4}$ precursor placed in an alumina crucible was decomposed in a muffle furnace in air in the temperature range from 250 to $800^{\circ} \mathrm{C}$. These temperatures were dwelled for 2 hours with a heating rate of $10{ }^{\circ} \mathrm{C} \cdot \mathrm{min}^{-1}$. The samples were cool down to room temperature after turning off the furnace and stored in a desiccator. $\mathrm{Ni}_{1-\mathrm{x}} \mathrm{O}$ materials prepared at $\mathrm{X}{ }^{\circ} \mathrm{C}$ are hereafter labelled as $\mathrm{NiO}-\mathrm{X}$. 


\subsection{Synthesis of nitrogen doped nickel oxide}

$200 \mathrm{mg}$ of $\mathrm{Ni}_{3} \mathrm{O}_{2}(\mathrm{OH})_{4}$ precursor powder was placed in a tubular furnace under $\mathrm{N}_{2}$ flow. The furnace was purged during 10 minutes before introducing $\mathrm{NH}_{3}$ flow $\left(10 \mathrm{~L}^{-1}{ }^{-1}\right)$. Then, the temperature was raised in a the $200-350^{\circ} \mathrm{C}$ range with a heating rate of $10^{\circ} \mathrm{C} \cdot \mathrm{min}^{-1}$ and dwelled for 30 minutes. Finally, the tubular furnace was cooled to room temperature by turning it off and the product was stored in a desiccator. $\mathrm{Ni}_{1-\mathrm{x}} \mathrm{O}$ materials prepared at $\mathrm{X}{ }^{\circ} \mathrm{C}$ are hereafter labelled as NiO-N-X.

\section{Results and discussion}

\subsection{Characterization of nickel oxyhydroxide nanoparticles}

In order to prepare undoped and nitrogen-doped nickel oxide nanoparticules with a large amount of nickel vacancies, we have proceeded as in our previous work on $\mathrm{N}$-doped $\mathrm{ZnO}(\mathrm{ZnO}: \mathrm{N})$ [8] and highly $\mathrm{Zn}$-deficient $\mathrm{ZnO}$ nanoparticles [12] with zinc peroxide as precursor. Indeed, like $\mathrm{ZnO}_{2}$, nickel (oxy)hydroxide compounds $\left(\mathrm{Ni}^{2+}{ }_{1-\mathrm{x}} \mathrm{Ni}^{3+}{ }_{\mathrm{x}} \mathrm{O}_{\mathrm{x}}(\mathrm{OH})_{2-\mathrm{x}}\right.$ with $\left.0 \leq \mathrm{x} \leq 1\right)$, are very unstable oxygenrich precursors which decompose at low temperature $\left(\leq 400^{\circ} \mathrm{C}\right)$ into the cubic-type $\mathrm{NiO}$ structure [13-15]. Consequently, the thermal decomposition of $\mathrm{Ni}^{3+}$-rich precursors such $\mathrm{Ni}_{3} \mathrm{O}_{2}(\mathrm{OH})_{4}$ is expected to favor the presence of $\mathrm{Ni}^{3+}$ and thus to promote the stabilization of nickel vacancies in the resulting nickel oxide. The observed XRD pattern of as-prepared oxyhydroxide is displayed in Figure 1. All the very broad diffraction peaks can be attributed to the $\mathrm{Ni}_{3} \mathrm{O}_{2}(\mathrm{OH})_{4}$ phase (JCPDS file 06-0144) that crystallizes in a structure type related to that of lamellar $\mathrm{Ni}(\mathrm{OH})_{2}[16]$. To determine the $\mathrm{Ni}^{3+} / \mathrm{Ni}^{2+}$ ratio and thus to confirm the chemical composition of $\mathrm{Ni}_{3} \mathrm{O}_{2}(\mathrm{OH})_{4}$, X-ray photoelectron spectroscopy experiments at the $\mathrm{Ni}$ threshold and magnetic susceptibility measurements were carried out. Figure 2 depicts the Ni 2p XPS spectrum of $\mathrm{Ni}_{3} \mathrm{O}_{2}(\mathrm{OH})_{4}$ and its inverse susceptibility versus temperature. The oxidation states of nickel have been determined from the position in energy of Ni $2 p_{3 / 2}$ XPS peak. Namely, binding energies (BE) of 852.6, 854.6 and 
$856.1 \mathrm{eV}$ are assigned to $\mathrm{Ni}^{0}, \mathrm{Ni}^{2+}$ and $\mathrm{Ni}^{3+}$ species, respectively [17]. The peak deconvolution of

Ni $2 p_{3 / 2}$ state (Fig. 2a) clearly indicates two oxidation states of nickel; Ni(II) and Ni(III). Ni ${ }^{3+} 2 p_{3 / 2}$ exhibits a $\mathrm{BE}$ at $855.8 \mathrm{eV}$ with a peak surface area of $63 \%$, while $\mathrm{Ni}^{2+} 2 \mathrm{p}_{3 / 2}$ exhibits a $\mathrm{BE}$ at 854.3 $\mathrm{eV}$ with a peak surface area of $37 \%$. The resulting $\mathrm{Ni}^{3+} / \mathrm{Ni}^{2+}$ ratio equals 2 . This ratio can be also estimated from magnetism measurements (Fig. 2b) with the value of the Curie constant (C) calculated from the curve $1 / \chi=f(T)$. Using the slope coefficient represented by a grey dashed line, we have determined a Curie constant of 0.63 (SI units) and a magnetic moment $\mu_{\text {eff }}=\sqrt{ }(8 * \mathrm{C})=$ $2.24 \mu_{B}$. Considering the experimental magnetic moments $\left(\mu_{e f f}\right)$ of $\mathrm{Ni}^{2+}$ and $\mathrm{Ni}^{3+}\left(3.2\right.$ and $1.7 \mu_{B}$ respectively), we calculate the ratio $\mathrm{Ni}^{3+} / \mathrm{Ni}^{2+} \approx 2$. According to the nickel oxyhydroxide formulation $\mathrm{NiO}_{\mathrm{x}}(\mathrm{OH})_{\mathrm{y}}$, the formula is well balanced with two $\mathrm{Ni}^{3+}$ for one $\mathrm{Ni}^{2+}$ in agreement with the $\mathrm{Ni}_{3} \mathrm{O}_{2}(\mathrm{OH})_{4}$ chemical composition identified from the JCDPS database (Fig. 1). The $\mathrm{Ni}_{3} \mathrm{O}_{2}(\mathrm{OH})_{4}$ powder has also a high specific surface area of $234 \mathrm{~m}^{2} \cdot \mathrm{g}^{-1}$ (Table 1) suitable for the synthesis of nickel oxide nanoparticles [18]. This agrees with particles size estimated to be around 2-3 nm from a TEM analysis (Fig. 3a), that explains the overall feature of the X-ray diffraction pattern.

\subsection{Thermal decomposition of nickel oxyhydroxide nanoparticles}

\subsubsection{Decomposition of nickel oxyhydroxide in air}

Figure 4 represents the temperature evolution of in situ XRD patterns recorded during the decomposition of $\mathrm{Ni}_{3} \mathrm{O}_{2}(\mathrm{OH})_{4}$ in air. The phase transformation from the lamellar oxyhydroxide structure into the $\mathrm{NiO}$ cubic structure $\left(\mathrm{NaCl}\right.$ type) occurs around $150-200{ }^{\circ} \mathrm{C}$. From 200 to $700{ }^{\circ} \mathrm{C}$, the full width at half maximum (FWHM) of the diffraction peaks decreases which attests a gradual increase of the crystallite size of $\mathrm{NiO}$ with temperature. The picture in inset of Figure 4 shows the sample after a $700{ }^{\circ} \mathrm{C}$ heating. The color of the as-prepared $\mathrm{NiO}$ sample is grey-black [19], but 
becomes green at temperatures typically above $800^{\circ} \mathrm{C}$ as expected for stoichiometric NiO. Figure 5 shows the evolution of the density of prepared "NiO" samples versus the decomposition temperature of $\mathrm{Ni}_{3} \mathrm{O}_{2}(\mathrm{OH})_{4}$. The densities measured for samples prepared up to $600{ }^{\circ} \mathrm{C}$ deviates from the theoretical density of stoichiometric bulk $\mathrm{NiO}(6.81)$. For samples prepared below $350^{\circ} \mathrm{C}$ the density is drastically lower than that expected and rises strongly with increasing temperature. For samples prepared at higher temperature $\left(\geq 400^{\circ} \mathrm{C}\right)$, the density is still lower than expected but evolves linearly (see the dashed line) until reaching the theoretical density of stoichiometric nickel oxide at $750^{\circ} \mathrm{C}$. The low density measured for samples prepared below $600^{\circ} \mathrm{C}$ could indicate the formation of nickel oxide nanoparticles deficient in nickel (i.e. $\mathrm{Ni}_{1-\mathrm{x}} \mathrm{O}$ ) similarly as what was observed during the preparation of zinc deficient zinc oxide [12]. To estimate the amount of nickel vacancies the following equations were used $(2,3)$ :

$$
d_{\text {exp }}=\frac{Z \times M_{\text {comp }}}{N_{A} \times V_{\text {ref }}}(2) \quad x=1-\frac{M_{\text {comp }}-M_{O}}{M_{N i}}
$$

with $\mathrm{d}_{\text {exp }}$ the measured density; $\mathrm{Z}$ the atomic number; $\mathrm{M}_{\text {comp }}$ the experimental molar weight of the compound; $\mathrm{N}_{\mathrm{A}}$ the Avogadro's number; $\mathrm{V}_{\text {ref }}$ the refined cell volume; $\mathrm{M}_{\mathrm{O}}$ and $\mathrm{M}_{\mathrm{Ni}}$ the oxygen and nickel molar weights respectively.

The density value measured for $\mathrm{Ni}_{1-\mathrm{x}} \mathrm{O}$ prepared at $250{ }^{\circ} \mathrm{C}(\mathrm{NiO}-250)$ would almost correspond to a $50 \%$ nickel deficient $\mathrm{Ni}_{1-\mathrm{x}} \mathrm{O}$ material. For NiO-500, the amount of nickel vacancy is estimated to be $20 \%$. Such low densities are correlated to a high specific surface area and low particles size (see below) and the strong propensity of the material to exhibit oxygen or hydroxide terminated surfaces. Due to the nanoscale of the particles, surface moisturization and carbonatation are likely to happen leading to lower measured densities, thus the estimated vacancy rate is overestimated. A Rietveld refinement on NiO-500 leads to a lower value $(\approx 10 \%)$ taking more account of the "bulk" feature of the nanoparticles. The effective vacancy rate is probably intermediate between those 
values. Nickel oxyhydroxide seems to be an ideal candidate to prepare Ni-poor NiO samples with tunable $\mathrm{Ni}$ deficiency via the control of the decomposition temperature of the precursor. The characterization of the nickel oxides morphology was investigated by TEM microscopy (Fig. 3b, 3c), BET specific surface areas and XRD to calculate the crystallites size by Rietveld refinement (Table 1). TEM images confirm the nanostructuration of NiO-250 ( similar case to $\left.\mathrm{Ni}_{3} \mathrm{O}_{2}(\mathrm{OH})_{4}\right)$ as agglomerates of nanoparticles $(2-3 \mathrm{~nm})$. As observed by XRD, the increase in temperature allows the further crystallization of $\mathrm{NiO}$ samples with larger particles sizes. In fact, $\mathrm{NiO}-500$ is still nanostructured with dispersed particles sizes around 10-15 nm. According to Table 1 the crystallites sizes are very close to the particles sizes determined by TEM analyses. In order to optimize the performances of $\mathrm{NiO}$ in $\mathrm{p}$-DSSCs, high specific surface area is necessary to coat a maximum number of dye molecules on $\mathrm{NiO}$ nanoparticles. Thus, we have also measured the specific surface areas of Ni-poor $\mathrm{NiO}$ samples. The results demonstrate for $\mathrm{NiO}-250$ a very high specific surface area close to $250 \mathrm{~m}^{2} \cdot \mathrm{g}^{-1}$ that is 3 times higher than that of Inframat $\mathrm{NiO}\left(\approx 80 \mathrm{~m}^{2} \cdot \mathrm{g}^{-1}\right)$ commonly used as a reference in p-DSSCs. The thermal treatment at $250{ }^{\circ} \mathrm{C}$ maintains the high specific surface area of the nickel precursor despite the structural change from $\mathrm{Ni}_{3} \mathrm{O}_{2}(\mathrm{OH})_{4}$ to $\mathrm{NiO}$. Note that the specific surface area drops to $42 \mathrm{~m}^{2} \cdot \mathrm{g}^{-1}$ for NiO-500, due to the increase in particles sizes.

\subsubsection{Decomposition of nickel oxyhydroxide under ammonia}

To our knowledge, the stabilization of a nitrogen-doped nickel oxide powder has not been evidenced yet. Only theoretical study [20] or N-doped NiO film [21] have been recently reported. However, the study of the decomposition of $\mathrm{Ni}_{3} \mathrm{O}_{2}(\mathrm{OH})_{4}$ under ammonia flow allows the stabilization of $\mathrm{N}$-doped $\mathrm{NiO}$ at low temperatures (see NiO-N-250). Indeed, Figure 6 represents the evolution of XRD patterns of $\mathrm{Ni}_{3} \mathrm{O}_{2}(\mathrm{OH})_{4}$ nitridation at temperatures ranging from 200 to $350{ }^{\circ} \mathrm{C}$. The investigated temperatures range is narrower than the one for previous $\mathrm{Ni}_{1-\mathrm{x}} \mathrm{O}$ materials because of the rapid reduction of nickel under ammonia at $\mathrm{T} \geq 350^{\circ} \mathrm{C}$. At temperatures below $250{ }^{\circ} \mathrm{C}$ a 
NiO-type cubic phase is formed with very broad peaks. When the nitridation temperature is over $300{ }^{\circ} \mathrm{C}$, a shoulder on the (200) reflection of $\mathrm{NiO}$ appears at $\sim 44.5^{\circ} 2 \theta$ that corresponds to the most expected intense peak of $\mathrm{Ni}_{3} \mathrm{~N}$ (111 reflection) (JCPDS file 89-5144). Over $350{ }^{\circ} \mathrm{C}, \mathrm{Ni}_{3} \mathrm{~N}$ is unambiguously formed. For higher temperatures, nickel cations are definitely reduced into elemental nickel. To assert the insertion of $\mathrm{N}$ in NiO-N-250, N(1s) XPS experiments were carried out. Figure 7 displays for NiO-250 no characteristic signal of nitrogen, whereas NiO-N-250 exhibits a $\mathrm{N} 1 \mathrm{~s} \mathrm{BE}$ peak at $398.2 \mathrm{eV}$. It proves unambiguously the presence of nitrogen into the $\mathrm{NiO}$ host lattice [8]. The nitrogen content in NiO-N-250 was determined to be $0.8 \mathrm{wt}$. $\%$ whereas the nitrogen amount in $\mathrm{NiO}-250$ and $\mathrm{Ni}_{3} \mathrm{O}_{2}(\mathrm{OH})_{4}$ was measured to 0.11 and 0.19 wt. \% respectively. The morphology of NiO-N-250 was investigated by TEM analysis (Fig. 3d), XRD and BET specific surface area (Table 1). The results are quite similar to those of NiO-250, i.e. nanoparticles of 2-3 $\mathrm{nm}$ in diameter are observed in agreement with the calculated crystallites sizes. An important result is the conservation under nitridation of the high specific surface area that shifts from 250 to 200 $\mathrm{m}^{2} \cdot \mathrm{g}^{-1}$ from NiO-250 to NiO-N-250.

\section{Conclusion}

The thermal decomposition of nickel oxyhydroxide nanoparticles was thoroughly studied in order to control the particles size of the as-prepared $\mathrm{NiO}$ nanopowders. The determination of the $\mathrm{Ni}^{3+} / \mathrm{Ni}^{2+}$ ratio by XPS and magnetism in the nickel oxyhydroxide confirms the $\mathrm{Ni}_{3} \mathrm{O}_{2}(\mathrm{OH})_{4}$ formulation. The decomposition of this compound in air at temperatures lower than $600{ }^{\circ} \mathrm{C}$ leads to nonstoichiometric $\mathrm{NiO}$ nanoparticles with tunable nickel vacancies concentration and high specific surface areas. Additionally, the stabilization of nitrogen-doped $\mathrm{NiO}$ is possible by low temperature nitridation of $\mathrm{Ni}_{3} \mathrm{O}_{2}(\mathrm{OH})_{4}$. All these modified-NiO materials aim to be tested soon in a p-DSSC. 


\section{Acknowledgement}

We are grateful to Eric Gautron, Jonathan Hamon (IMN) and Thierry Guizouarn (ISCR) for their help in TEM, XPS and magnetic studies respectively. 


\section{References}

[1] B. O'Regan, M. Grätzel, Nature 353 (1991) 737.

[2] F. Odobel, L. Le Pleux, Y. Pellegrin, E. Blart, Acc. Chem. Res. 43 (2010) 1063.

[3] S. Powar, T. Daeneke, M. T. Ma, D. Fu, N. W. Duffy, G. Götz, M. Weidelener, A. Mishra, P. Bäuerle, L. Spiccia, U. Bach, Angew. Chem. Int. Ed. 52 (2013) 602.

[4] H. Kawazoe, M. Yasukawa, H. Hyodo, M. Kurita, H. Yanagi, H. Hosono, Nature 389 (1997) 939.

[5] A. Renaud, B. Chavillon, L. Le Pleux, Y. Pellegrin, E. Blart, M. Boujtita, T. Pauporté, L. Cario, S. Jobic, F. Odobel, J. Mater. Chem. 22 (2012) 14353.

[6] D. Xiong, Z. Xu, X. Zeng, W. Zhang, W. Chen, X. Xu, M. Wang, Y-B. Cheng, J. Mater. Chem. 22 (2012) 24760.

[7] Z. Shi, H. Lu, Q. Liu, F. Cao, J. Guo, K. Deng, L. Li, Nanoscale Res. Lett 9 (2014) 608.

[8] B. Chavillon, L. Cario, A. Renaud, F. Tessier, F. Cheviré, M. Boujtita, Y. Pellegrin, E. Blart, A. Smeigh, L. Hammarström, F. Odobel, S. Jobic, J. Am. Chem. Soc. 134 (2012) 464.

[9] T. Roisnel, J. Rodríguez-Carvajal, Mater. Sci. Forum 378-381 (2001) 118.

[10] K. Nakagawa, R. Konaka, T. Nakata, J. Org. Chem. 27 (5) (1962) 1597.

[11] J. Pan, J. Du, Y. Sun, P. Wan, X. Liu, Y. Yang, Electrochim. Acta. 54 (2009) 3812.

[12] A. Renaud, L. Cario, X. Rocquefelte, P. Deniard, E. Gautron, E. Faulques, F. Cheviré, F. Tessier, S. Jobic. Sci. Rep. (2015). DOI:10.1038/srep12914.

[13] J. Pan, Y. Sun, P. Wan, Z. Wang, X. Liu, Electrochem. Commun. 7 (2005) 857. 
[14] M. S. Hamdan, Riyanto, M. R. Othman, Int. J. Electrochem. Sci. 8 (2013) 4747.

[15] M. M. Kashani Motlagh, A. A. Youzbashi, F. Hashemzadeh, L. Sabaghzadeh, Powder Technol. 237 (2013) 562.

[16] M. Casas-Cabanas, J. Canales-Vázquez, J. Rodríguez-Carvajal, M. R. Palací, J. Am. Chem. Soc. 129 (2007) 5840.

[17] A.P. Grosvenor, M. C. Biesinger, R. St. C. Smart, N. S. McIntyre, Surf. Sci. 600 (2006) 1771.

[18] T.-L. Lai, J.-Y Liu, K.-F. Yong, Y.-Y. Shu, C.-B. Wang, J. Hazard. Mater. 157 (2008) 496.

[19] A. Renaud, B. Chavillon, L. Cario, L. Le Pleux, N. Szuwarski, Y. Pellegrin, E. Blart, E. Gautron, F. Odobel, S. Jobic, J. Phys. Chem. C 117 (2013) 22478.

[20] R. Long, N. J. English, D. A. Mooney, Phys. Lett. A 374 (2010) 1184.

[21] F. Lin, D. T. Gillaspie, A. C. Dillon, R. M. Richards, C. Engtrakul, Thin Solid Films 527 (2013) 26. 


\section{Figures \& table captions}

Table 1. Summary of the specific surface areas, crystallites and particles sizes for $\mathrm{Ni}_{3} \mathrm{O}_{2}(\mathrm{OH})_{4}$, NiO-250, NiO-500 and NiO-N-250 samples.

Fig. 1. Powder X-ray diffraction pattern of nickel oxyhydroxide synthesized by precipitation route.

Fig 2. a) Ni $2 p$ XPS spectrum of $\mathrm{Ni}_{3} \mathrm{O}_{2}(\mathrm{OH})_{4}$; b) Magnetic properties of $\mathrm{Ni}_{3} \mathrm{O}_{2}(\mathrm{OH})_{4}$.

Fig 3. TEM images of a) $\mathrm{Ni}_{3} \mathrm{O}_{2}(\mathrm{OH})_{4}$; b) NiO-250; c) NiO-500; d) NiO-N-250 samples.

Fig 4. In situ XRD study patterns of the decomposition of $\mathrm{Ni}_{3} \mathrm{O}_{2}(\mathrm{OH})_{4}$ in air. The interval of temperature is $50^{\circ} \mathrm{C}$ between each XRD data.

Fig 5. Evolution of the density and $\mathrm{Ni}$ vacancies amount in prepared $\mathrm{Ni}_{1-\mathrm{x}} \mathrm{O}$ samples versus decomposition temperature in air with $\mathrm{Ni}_{3} \mathrm{O}_{2}(\mathrm{OH})_{4}$ as precursor.

Fig 6. X-ray diffraction patterns of $\mathrm{N}$-doped $\mathrm{NiO}$ materials issued from the ammonolysis of $\mathrm{Ni}_{3} \mathrm{O}_{2}(\mathrm{OH})_{4}$ at $200,250,300$ and $350^{\circ} \mathrm{C}$.

Fig 7. N 1s XPS spectra of NiO-250 and NiO-N-250 samples. 
Table 1. Summary of the specific surface areas, crystallites and particles sizes for $\mathrm{Ni}_{3} \mathrm{O}_{2}(\mathrm{OH})_{4}$, NiO-250, NiO-500 and NiO-N-250 samples.

\begin{tabular}{cccc}
\hline Sample & $\begin{array}{c}\text { Specific surface } \\
\text { area }\left(\boldsymbol{m}^{2} \cdot \mathbf{g}^{-\mathbf{1}}\right)\end{array}$ & $\begin{array}{c}\text { Crystallite size } \\
(\mathbf{n m})\end{array}$ & $\begin{array}{c}\text { Particle size } \\
(\mathbf{n m})\end{array}$ \\
\hline $\mathrm{Ni}_{3} \mathrm{O}_{2}(\mathrm{OH})_{4}$ & 234 & - & $2-3$ \\
$\mathrm{NiO}-250$ & 247 & 2.0 & $2-3$ \\
$\mathrm{NiO}-500$ & 42 & 9.1 & $10-15$ \\
$\mathrm{NiO}-\mathrm{N}-250$ & 198 & 1.8 & $2-3$ \\
\hline
\end{tabular}




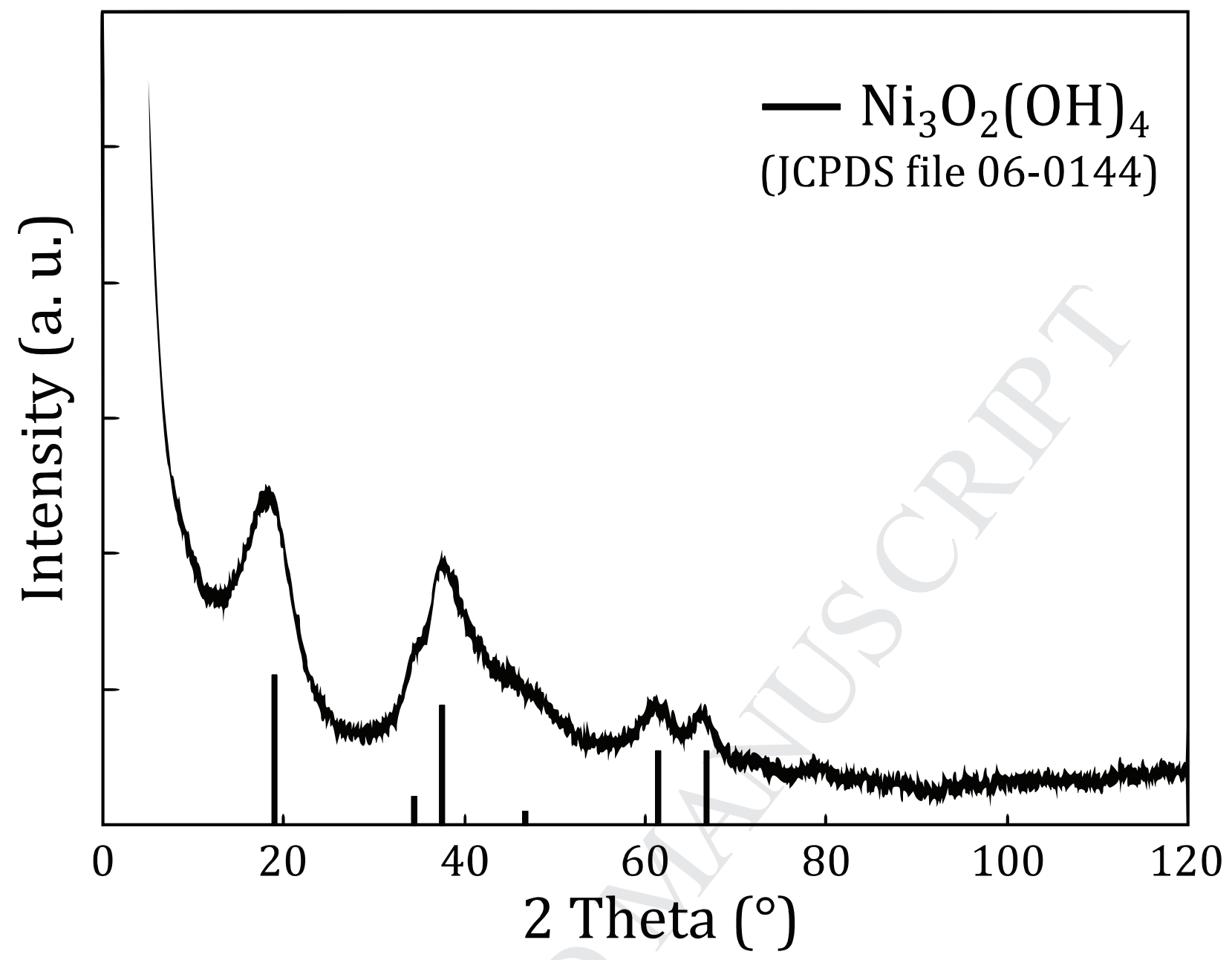

Fig. 1. Powder X-ray diffraction pattern of nickel oxyhydroxide synthesized by precipitation route. 

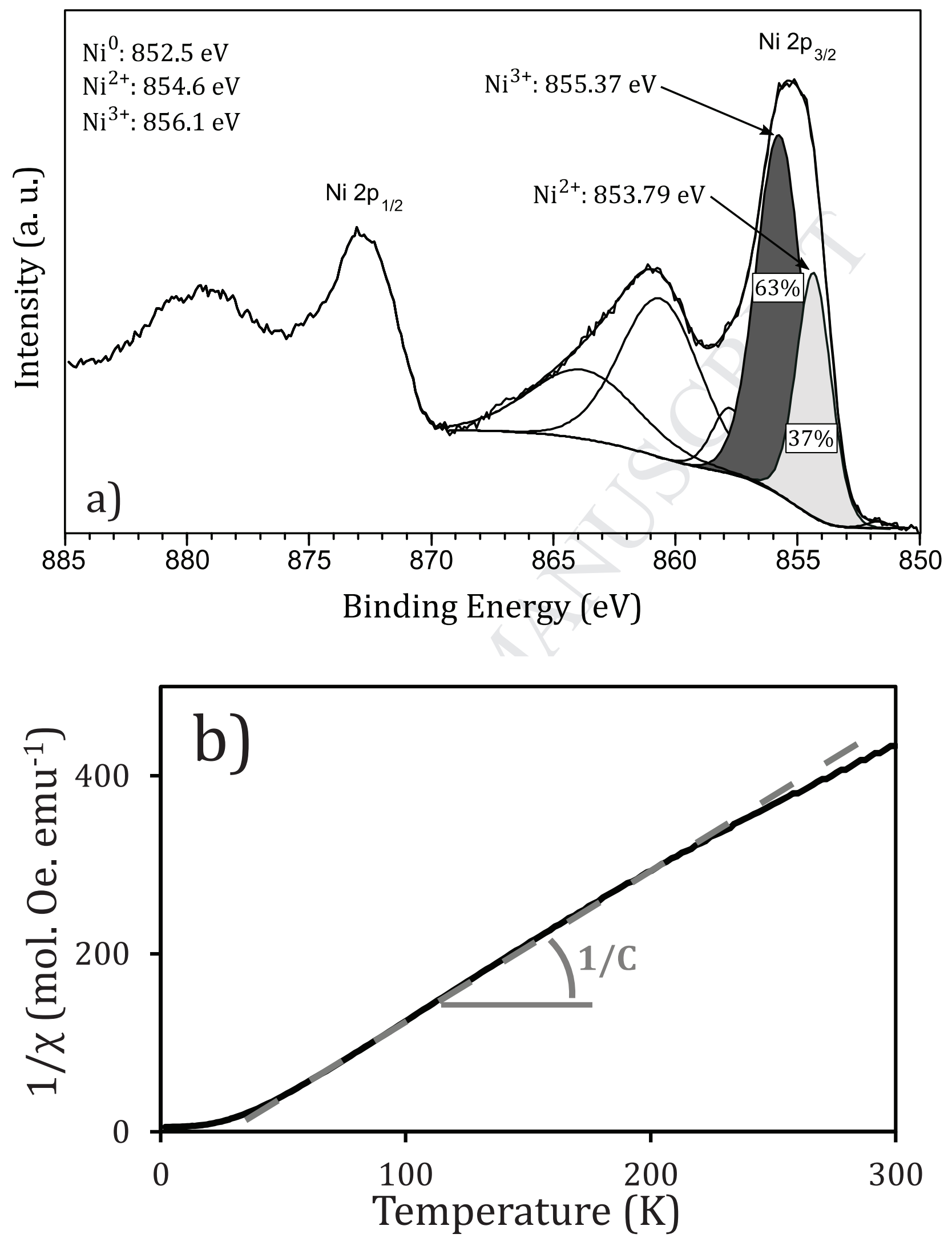

Fig 2. a) Ni 2p XPS spectrum of $\mathrm{Ni}_{3} \mathrm{O}_{2}(\mathrm{OH})_{4}$; b) Magnetic properties of $\mathrm{Ni}_{3} \mathrm{O}_{2}(\mathrm{OH})_{4}$. 

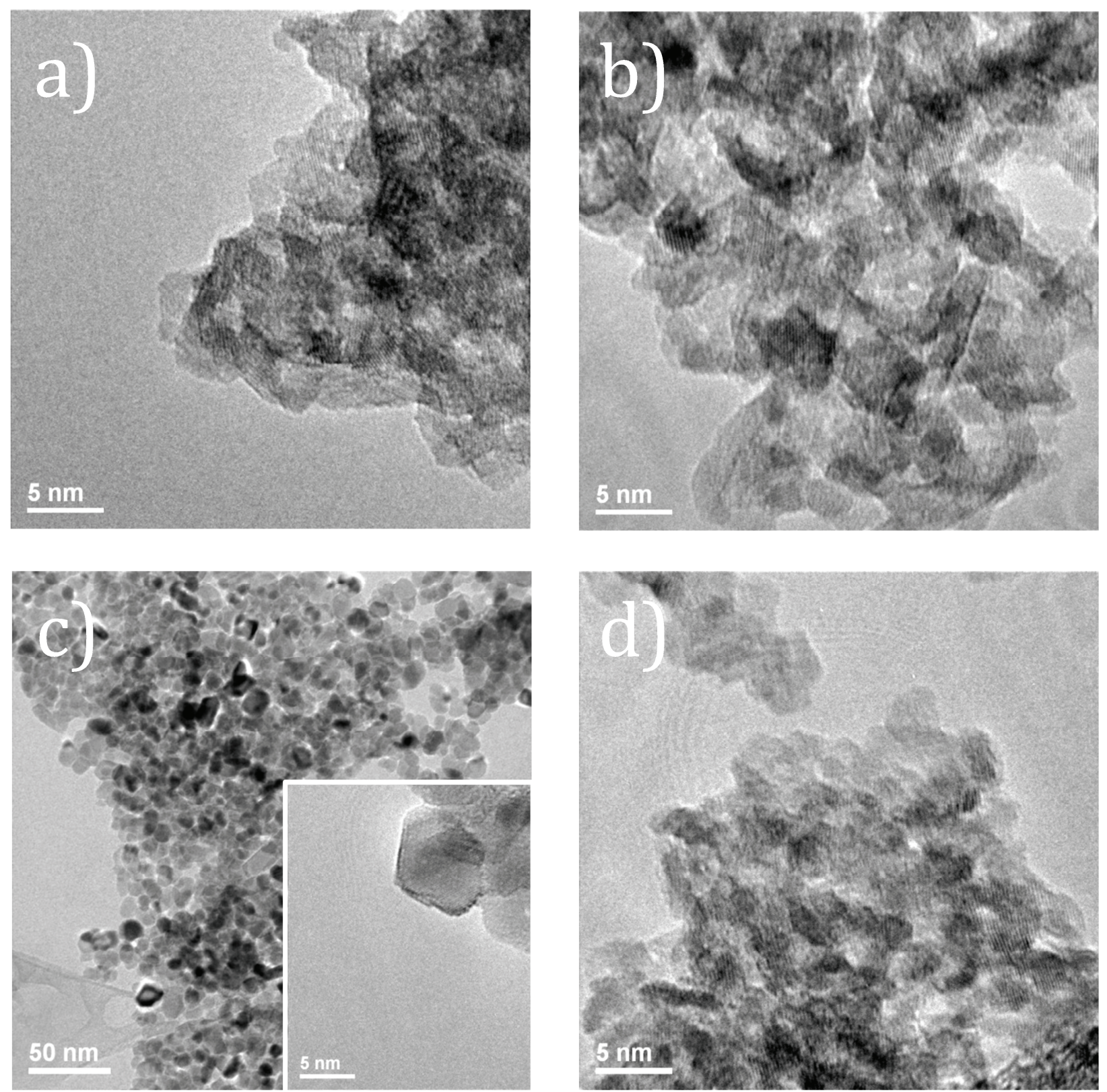

Fig 3. TEM images of a) $\mathrm{Ni}_{3} \mathrm{O}_{2}(\mathrm{OH})_{4}$; b) NiO-250; c) NiO-500; d) NiO-N-250 samples. 


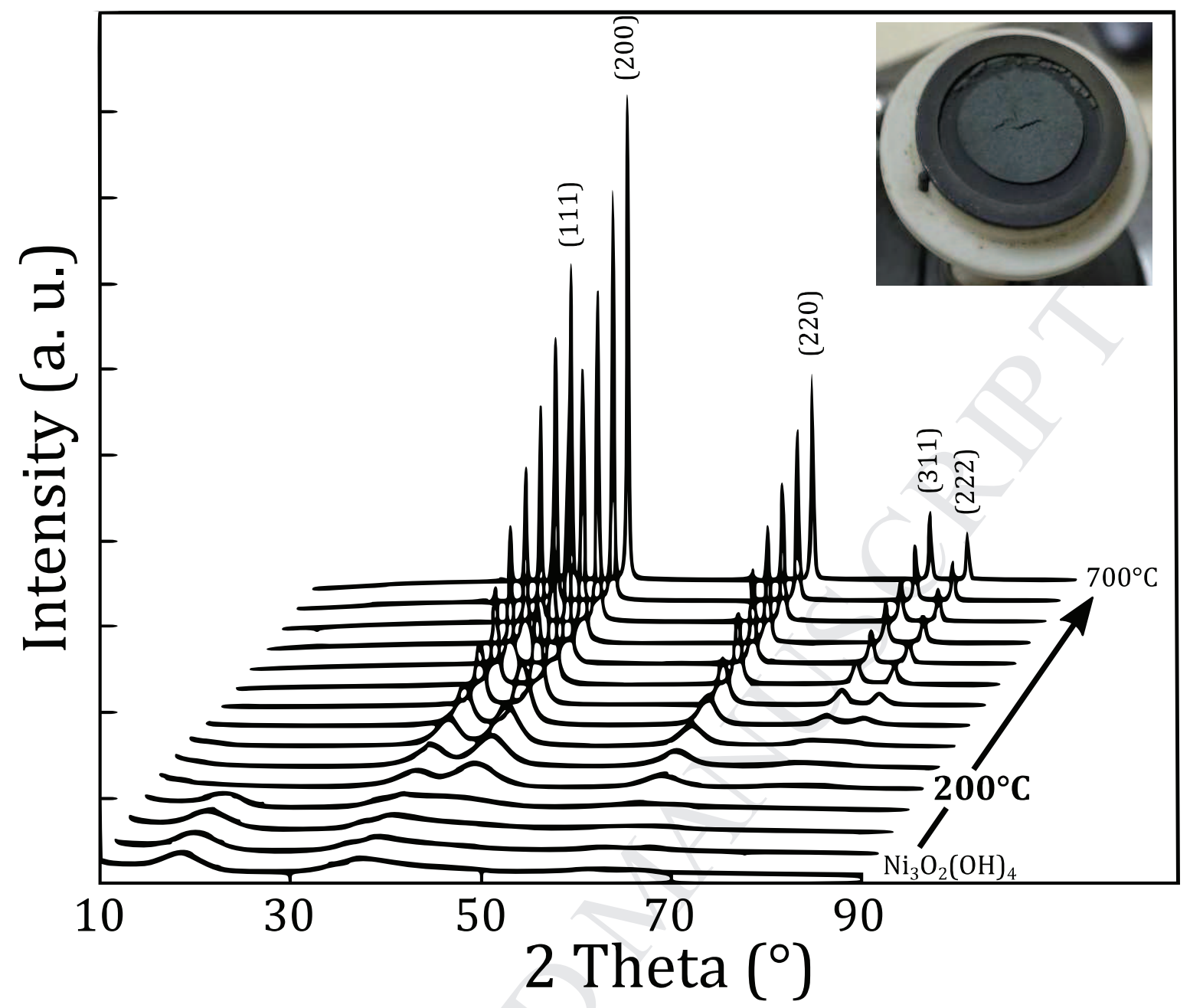

Fig 4. In situ XRD study patterns of the decomposition of $\mathrm{Ni}_{3} \mathrm{O}_{2}(\mathrm{OH})_{4}$ in air. The interval of temperature is $50^{\circ} \mathrm{C}$ between each XRD data. 


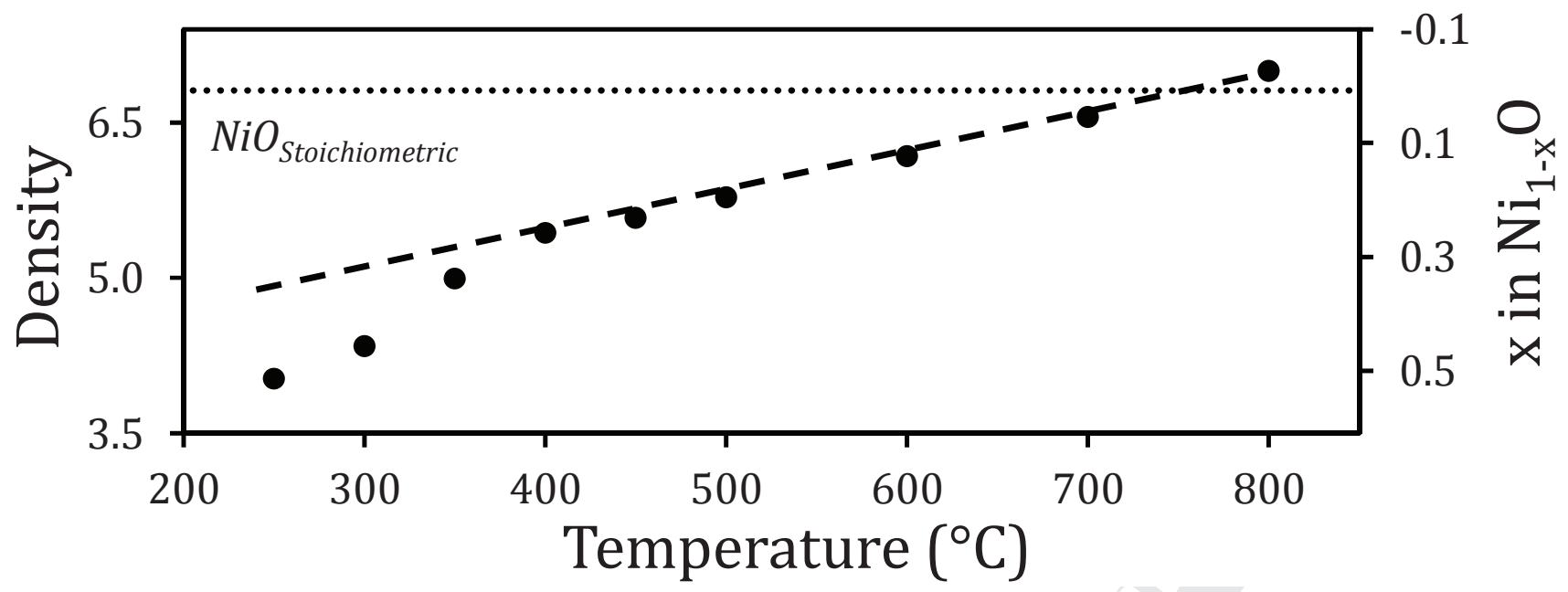

Fig 5. Evolution of the density and $\mathrm{Ni}$ vacancies amount in prepared $\mathrm{Ni}_{1-\mathrm{x}} \mathrm{O}$ samples versus decomposition temperature in air with $\mathrm{Ni}_{3} \mathrm{O}_{2}(\mathrm{OH})_{4}$ as precursor. 


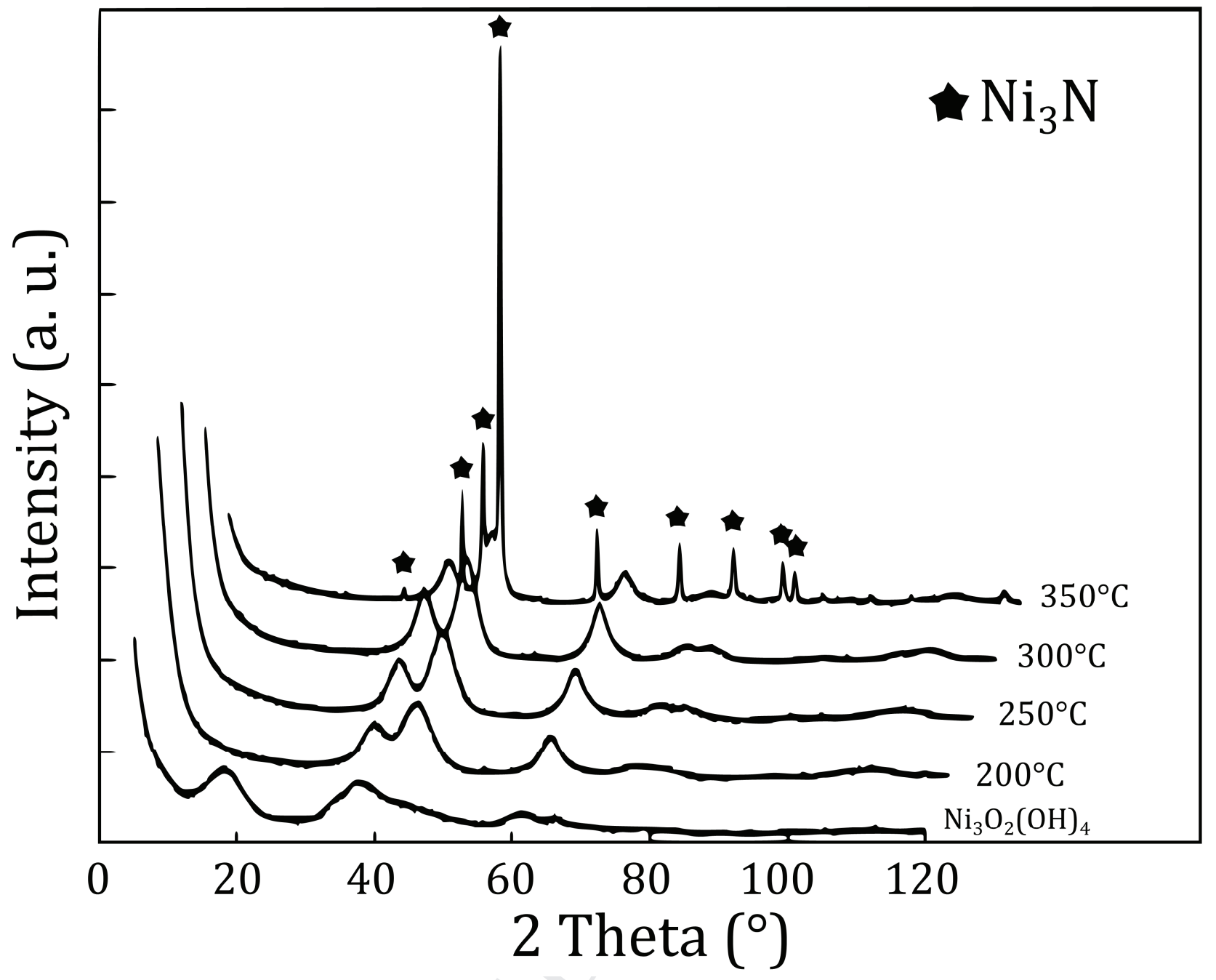

Fig 6. X-ray diffraction patterns of $\mathrm{N}$-doped $\mathrm{NiO}$ materials issued from the ammonolysis of $\mathrm{Ni}_{3} \mathrm{O}_{2}(\mathrm{OH})_{4}$ at $200,250,300$ and $350^{\circ} \mathrm{C}$. 


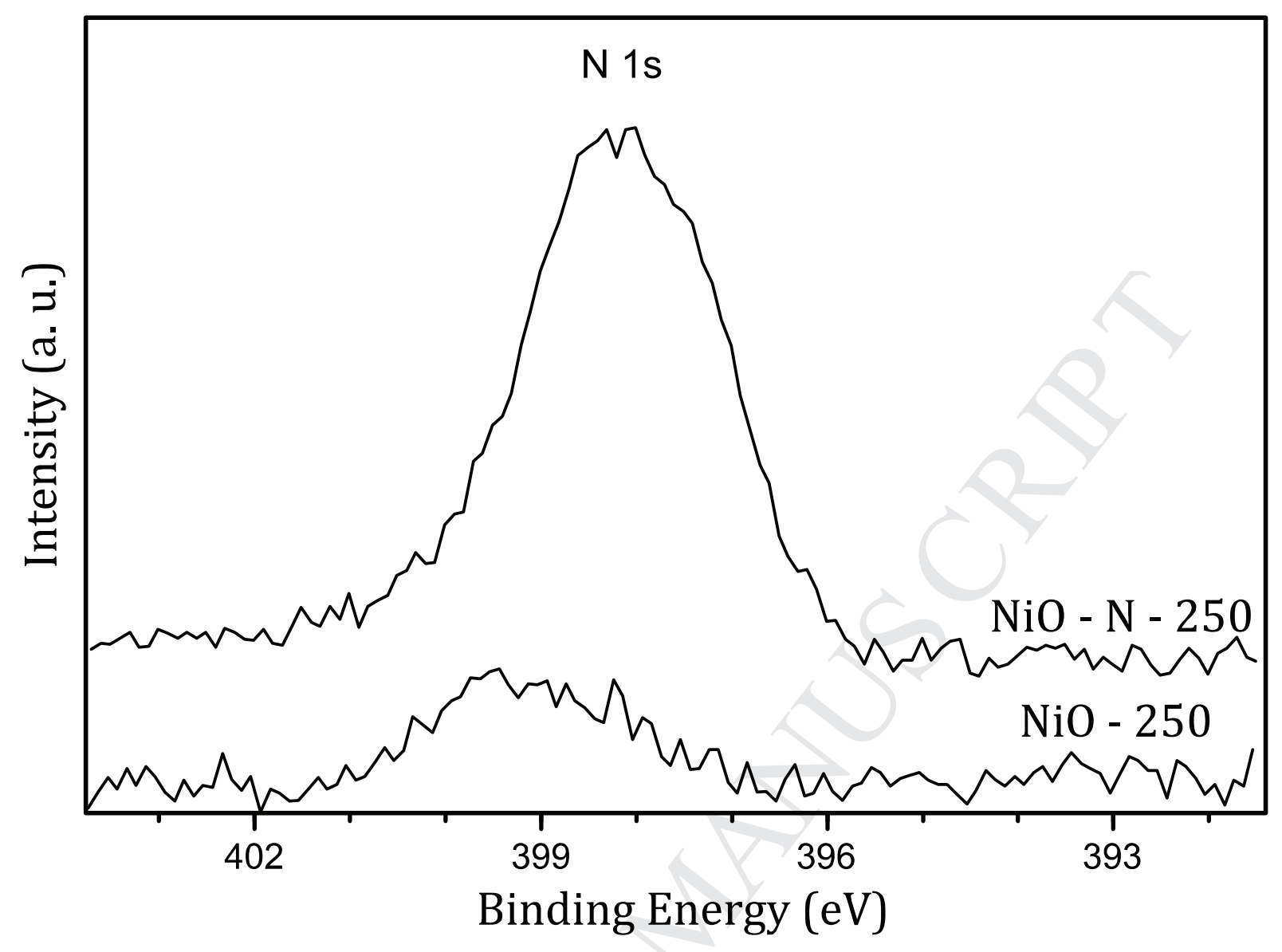

Fig 7. N 1s XPS spectra of NiO-250 and NiO-N-250 samples. 


\section{Highlights}

Synthesis of nickel precursor $\mathrm{Ni}_{3} \mathrm{O}_{2}(\mathrm{OH})_{4}$ nanoparticles with high $\mathrm{Ni}^{3+} / \mathrm{Ni}^{2+}$ ratio

Synthesis of $\mathrm{Ni}$-poor $\mathrm{NiO}$ nanoparticles by thermal decomposition of $\mathrm{Ni}_{3} \mathrm{O}_{2}(\mathrm{OH})_{4}$

Synthesis of $\mathrm{N}$-doped $\mathrm{NiO}$ nanoparticles by ammonolysis of $\mathrm{Ni}_{3} \mathrm{O}_{2}(\mathrm{OH})_{4}$ 